Personalidade Acadêmica Homenageada:

Raymundo Juliano Feitosa (Universidade Federal do Rio Grande do Norte - UFRN)

\title{
PARA ALÉM DAS DORES DO PARTO: UM ESTUDO SOBRE A VIOLAÇÃO DOS DIREITOS NOS AMBIENTES OBSTÉTRICOS
}

\author{
JÚLIA MACEDO CAMPOLINA DINIZ
}

Graduanda em Direito, na modalidade Integral, pela Escola Superior Dom Helder Câmara, Belo Horizonte. E-mail julia.macedocd@outlook.com

\section{CAIO AUGUSTO SOUZA LARA}

Mestre e Doutor em Direito pela Faculdade de Direito da Universidade Federal de Minas Gerais - UFMG. Professor da Escola Superior Dom Helder Câmara. Pesquisador Associado ao Programa RECAJ-UFMG - Acesso à Justiça e Solução de Conflitos. Secretário de Comunicação do Conselho Nacional de Pesquisa e Pósgraduação em Direito - CONPEDI. Belo Horizonte-MG. E-mail: caiolarabh@yahoo.com.br

\section{RESUMO}

O tema-problema da pesquisa que se desenvolve é a violência obstétrica no Brasil e seus reflexos jurídicos. A violência obstétrica é um tema de extrema relevância não apenas por afetar milhares de mulheres diariamente, mas por se tratar da violação sistemática de uma série de direitos básicos constitucionalmente guardados. O machismo estrutural e a forte herança patriarcal da sociedade brasileira não deveriam ameaçar os direitos da mulher, apesar de cotidianamente 0 fazerem- e as salas de parto não têm sido exceção a essa realidade. Abuso verbal, negligência, feitura de procedimentos desnecessários, e/ou coercivos ou não consentidos e/ou sem anestesia, recusa de administrar analgésicos, administração abusiva de fármacos, violações graves de privacidade, negação do direito a acompanhante e execução de procedimentos e manobras não recomendadas pela 
Personalidade Acadêmica Homenageada:

Raymundo Juliano Feitosa (Universidade Federal do Rio Grande do Norte - UFRN)

Organização Mundial de Saúde e pelo Ministério da Saúde são formas de violência obstétrica, e 1 a cada 4 mulheres são vitimadas por ela no Brasil. Consequência direta do machismo estrutural e expressão da eterna fragilidade dos direitos das mulheres, tal violência é um problema e o não reconhecimento do seu nome, como foi recentemente proposto pelo ministério, não o faz menos real. Na verdade, quanto menos for dito e feito sobre ela, mais frequente ela será e menos amparo terá a vítima que optar por denunciar. $O$ combate à violência contra a mulher deve ser constante, e não pode estar desvinculado do ambiente ginecológico e obstétrico. Simone de Beauvoir afirmava que as mulheres precisavam se manter vigilantes a todo tempo, pois seus direitos não eram permanentes; o fato de que ainda hoje o direito feminino de autonomia em relação ao próprio corpo é colocado em xeque comprova a tese da autora. O problema objeto da investigação científica aqui proposta é: quais são os desdobramentos jurídicos e sociológicos da violência obstétrica no Brasil? A partir das reflexões preliminares sobre o tema, é possível afirmar inicialmente que a violência obstétrica é consequência direta de uma cultura marcada pela herança patriarcal, desvalorização sistemática da mulher, da vida e da infância e da juventude. Não se espera, de uma sociedade com tais características, repentina reverência na hora do parto- ambiente que reúne num só cômodo mulher, infância e vida. É objetivo geral do trabalho analisar os aspectos jurídicos e sociológicos da violência obstétrica, determinar em que ambiente ela ocorre, quais são as suas vítimas, analisar quais são suas possíveis causas e consequências. À luz dos direitos Humanos, é objetivo dessa pesquisa, também, trazer visibilidade ao tema e conscientizar a população de quais são dos direitos da gestante e do feto. $\mathrm{A}$ pesquisa que se propõe pertence à vertente metodológica jurídico-sociológica. No tocante ao tipo de investigação, foi escolhido, na classificação de Witker (1985) e Gustin (2010), o tipo jurídico-projetivo. O raciocínio desenvolvido na pesquisa será predominantemente dialético. De acordo com a técnica de análise de conteúdo, afirma-se que se trata de uma pesquisa teórica, o que será possível a partir da análise de conteúdo dos textos doutrinários, normas e demais dados colhidos na pesquisa. A partir do exposto, conclui-se preliminarmente que a violência obstétrica é uma forma de violência de gênero, e que sua resolução passa necessariamente 
Personalidade Acadêmica Homenageada:

Raymundo Juliano Feitosa (Universidade Federal do Rio Grande do Norte - UFRN)

por duas esferas da sociedade: a cultural e a jurídica. Os elementos da sociedade que perpetuam essa violência devem ser erradicados, e, para que os ambientes obstétricos sejam seguros, é necessário que as vítimas tenham amparo legal, e que os profissionais da saúde sejam extensivamente orientados sobre aos direitos das gestantes, cabendo sanção àqueles que não for os respeitarem. Questões como parto, violência obstétrica e violação dos direitos da mulher não podem ser negligenciadas.

PALAVRAS-CHAVE: Direitos Humanos; Violência Obstétrica; Violência de Gênero; Direitos da Mulher.

\section{REFERÊNCIAS}

ADICHIE, Chimamanda Ngozi. Sejamos todas feministas. $1^{\circ}$.ed. São Paulo: Companhia das Letras, 2015.

AZEREDO, Caroline Machado de Oliveira. "Dez anos de lei maria da penha: a importância da perspectiva de gênero no enfrentamento da violência" Revista Jurídica - UNICURITIBA -. ISSN 2316-753X. v.1 n.46, p. 494 - 514, 2017. Disponível em http://revista.unicuritiba.edu.br/index.php/RevJur/article/view/2126. Acesso em 22 mai. 2019.

BRASIL. Constituição da República Federativa do Brasil de 1988. Disponível em: http://www.planalto.gov.br/ccivil_03/constituicao/constituicao.htm. Acesso em: 30 abr. 2019.

FIOCRUZ. Casos de Violência Obstétrica no Brasil foram evidenciados pela Pesquisa da Rede Cegonha. Disponível em http://www.cee.fiocruz.br/radarods/?p=3210. Acesso em 22 mai. 2019.

GUSTIN, Miracy Barbosa de Sousa; DIAS, Maria Tereza Fonseca. (Re)pensando a pesquisa jurídica: teoria e prática. 3ª . ed. Belo Horizonte: Del Rey, 2010.

HUMAN Rights in Childbirth. Disponível em http://www.may28.org/human-rights-inchildbirth/. Acesso em 22 mai 2019.

TESSER, Charles Dalcanale; SENA, Lígia Moreira. Violência obstétrica no Brasil e o ciberativismo de mulheres mães: relato de duas experiências. Disponível em 
Personalidade Acadêmica Homenageada:

Raymundo Juliano Feitosa (Universidade Federal do Rio Grande do Norte - UFRN)

https://www.scielosp.org/scielo.php?pid=S141432832017000100209\&script=sci_arttext\&tIng=pt VIOLÊNCIA obstétrica é violência contra a mulher: mulheres em luta pela abolição da violência obstétrica. Sentido do Nascer. Disponível em http://www.sentidosdonascer.org/wordpress/wp-content/themes/sentidos-donascer/assets/pdf/controversias/Violencia-obstetrica-e-violencia-contra-a-mulher.pdf. Acesso em 20 mai. 2019.

WITKER, Jorge. Como elaborar una tesis en derecho: pautas metodológicas y técnicas para el estudiante o investigador del derecho. Madrid: Civitas, 1985. 